Supplement of Biogeosciences, 13, 5895-5916, 2016

http://www.biogeosciences.net/13/5895/2016/

doi:10.5194/bg-13-5895-2016-supplement

(C) Author(s) 2016. CC Attribution 3.0 License.

(c) (i)

Supplement of

\title{
An introduction to the Australian and New Zealand flux tower network - OzFlux
}

Jason Beringer et al.

Correspondence to: Jason Beringer (jason.beringer@uwa.edu.au)

The copyright of individual parts of the supplement might differ from the CC-BY 3.0 licence. 
Supplement Table S1: OzFlux site history.

\begin{tabular}{|c|c|c|}
\hline Site name & FLUXNET ID & Site history \\
\hline Adelaide River & AU-Ade & $\begin{array}{l}\text { Woodland savanna on shallow loamy sand (hydrolsol) with low level grazing pressure, fire frequency } 1 \text { in } 3 \\
\text { years. }\end{array}$ \\
\hline Alice Springs & AU-ASM & Pine Hill cattle station. Cattle grazing in low numbers has continued for decades. \\
\hline Arcturus & AU-Arc & $\begin{array}{l}\text { Pasture (to W) Lightly forested tussock grasslands: Crop (to E): 2011-June 2012: Barren land due to flooding, } \\
\text { followed by remediation work, June 2012-November 2012: Chickpeas, November 2012-June 2013: Fallow, } \\
\text { June 2013-November 2013: Wheat, November 2013-January 2014: Fallow }\end{array}$ \\
\hline Calperum & AU-Cpr & $\begin{array}{l}\text { Multi-stemmed, 3-5m high eucalypt trees centred 2-4m apart with limited mid-story species, extensive perennial } \\
\text { spinifex and occasional annual grasses. Regrowth of trees after fire } \sim 35 y e a r s \text { ago with sheep grazing ceased in } \\
\text { 1994. Site burned by wildfire in January } 2014 \text { and regrowth now occurring. }\end{array}$ \\
\hline Cape Tribulation & AU-Ctr & Selective logging finished. World Heritage, National Park fetch region. \\
\hline Cow Bay & AU-Cow & Selective logging finished. World Heritage, National Park fetch region. \\
\hline Cumberland Plains & AU-Cum & Not been managed but is a remnant woodland at the urban-wildland interface. \\
\hline Daly River Pasture & AU-DaP & $\begin{array}{l}\text { Tropical improved pasture ( } \mathrm{C}_{4} \text { grass and legume mixture), cleared 1982, low grazing pressure ( } \sim 1 \text { head ha-1), } \\
\text { fire } 1 \text { in } 5 \text { years. }\end{array}$ \\
\hline Daly River Savanna & AU-DaS & $\begin{array}{l}\text { Woodland savanna on deep sandy loam soils (kandosol), native pasture grazing, very low grazing pressure }(\sim 0.1 \\
\text { head } h^{-1} \text { ), fire } 1 \text { in } 5 \text { years. }\end{array}$ \\
\hline Dargo & AU-Drg & Low density historical and current grazing during the warmer months . \\
\hline
\end{tabular}




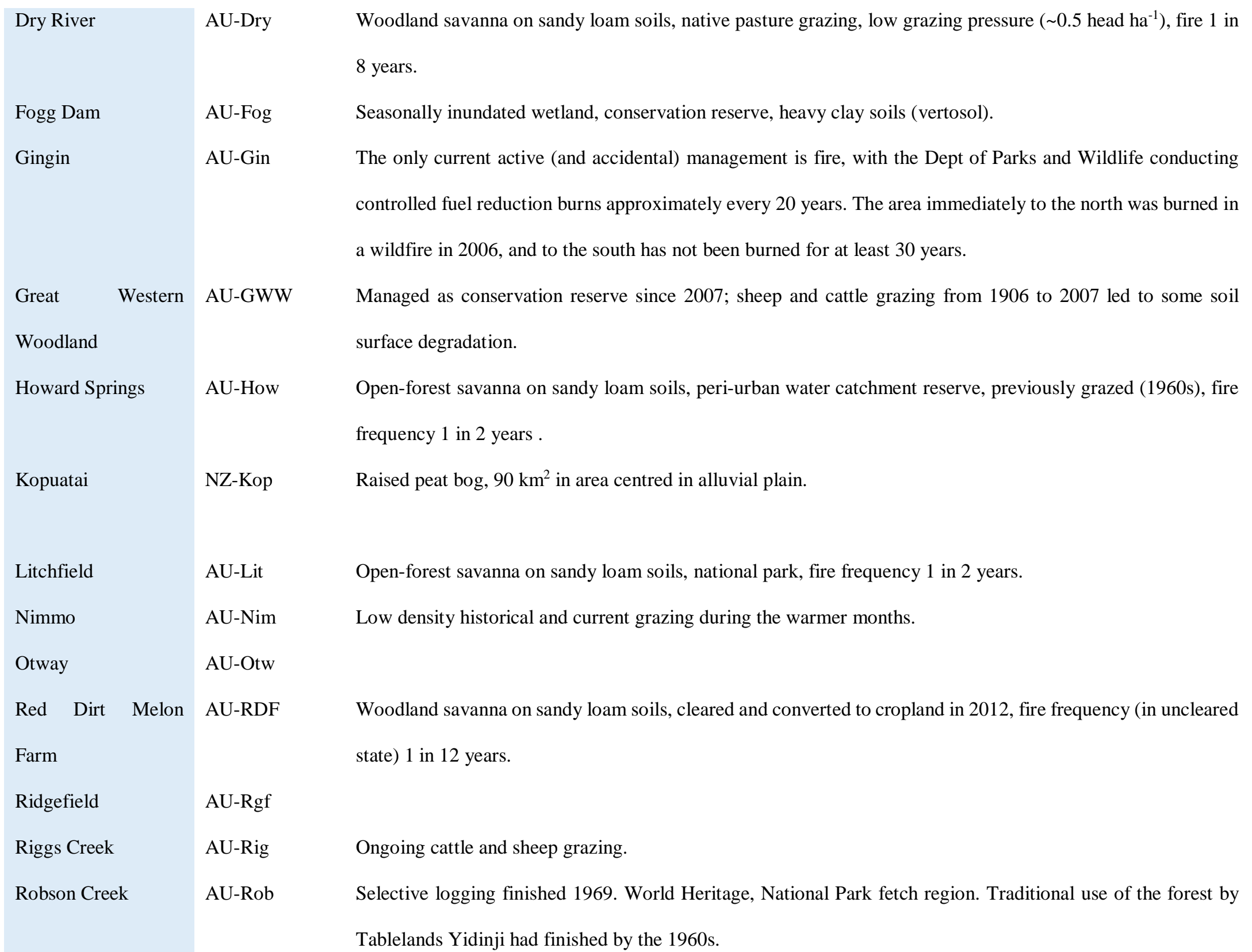

Dry River

AU-Dry

Fogg Dam

AU-Fog

Gingin

AU-Gin

Great Western

AU-GWW

Woodland

Howard Springs

AU-How .

Kopuatai

NZ-Kop

Litchfield

Nimmo

Otway

Red Dirt Melon

Farm

Ridgefield

Riggs Creek

Robson Creek

Woodland savanna on sandy loam soils, native pasture grazing, low grazing pressure ( $\sim .5$ head hä $\left.{ }^{-1}\right)$, fire 1 in 8 years.

Seasonally inundated wetland, conservation reserve, heavy clay soils (vertosol).

The only current active (and accidental) management is fire, with the Dept of Parks and Wildlife conducting controlled fuel reduction burns approximately every 20 years. The area immediately to the north was burned in a wildfire in 2006, and to the south has not been burned for at least 30 years.

Managed as conservation reserve since 2007; sheep and cattle grazing from 1906 to 2007 led to some soil surface degradation.

Open-forest savanna on sandy loam soils, peri-urban water catchment reserve, previously grazed (1960s), fire frequency 1 in 2 years .

Raised peat bog, $90 \mathrm{~km}^{2}$ in area centred in alluvial plain.

Open-forest savanna on sandy loam soils, national park, fire frequency 1 in 2 years.

AU-Nim

Low density historical and current grazing during the warmer months.

AU-Otw

AU-RDF

Woodland savanna on sandy loam soils, cleared and converted to cropland in 2012, fire frequency (in uncleared state) 1 in 12 years.

AU-Rgf

AU-Rig

AU-Rob

Ongoing cattle and sheep grazing.

Selective logging finished 1969. World Heritage, National Park fetch region. Traditional use of the forest by Tablelands Yidinji had finished by the 1960s. 


\begin{tabular}{|c|c|c|}
\hline Samford & Au-Sam & $\begin{array}{l}\text { Native woodland clearly over } 100 \text { years ago, grazed tropical native and improved grasses supporting subsistence } \\
\text { livestock production until 2009. Simulated grazing from } 2009 \text {. }\end{array}$ \\
\hline Sturt Plains & AU-Stp & $\begin{array}{l}\text { Mitchel grassland plain on cracking clay soils (vertosol), very low grazing pressure }\left(<0.1 \text { head ha }^{-1}\right) \text {, fire } 1 \text { in } \\
16 \text { years. }\end{array}$ \\
\hline Ti Tree East & AU-TTE & $\begin{array}{l}\text { Pine Hill cattle station. Cattle grazing ceased between } 2009 \text { - } 2013 \text { but was re-introduced in in July } 2014 \text { and } \\
\left.\text { stocked continuously in low-to-moderate densities ( } ~ 3000 \text { head of cattle on ca. } 700 \mathrm{~km}^{2}\right) \text {. }\end{array}$ \\
\hline Troughton Farm & NZ-Tr1 & Dairy farm with year-round grazing, ryegrass/clover pasture, all feed produced on-farm. \\
\hline Tumbarumba & AU-Tum & 2003 insect attack, 2004 selective logging in footprint. \\
\hline Virginia Park & AU-Vir & \\
\hline Wallaby Creek & AU-Wac & Old growth forest burned by stand replacing fire in Feb 2009 and now regrowing forest. \\
\hline Warra & $\mathrm{Au}-\mathrm{Wrr}$ & Natural forest that has originated from natural disturbance by period wildfire (most recent wildfire was in 1898). \\
\hline Whroo & AU-Whr & $\begin{array}{l}\text { Clearing in the broader area during the 19th century to supply timber for gold mining. It is also thought that } \\
\text { there was selective logging in the area during much of the 20th century. Some of this is most likely relatively } \\
\text { recent, with numerous tree stumps present at the site. }\end{array}$ \\
\hline Wombat & AU-Wom & $\begin{array}{l}\text { Site is a } \sim 25 \text { years old secondary regrowth forest with a tree height of } 21-25 \mathrm{~m} \text {. Forest management includes } \\
\text { rotational prescribed burns of understorey vegetation and shelter wood harvesting. }\end{array}$ \\
\hline Yanco & AU-Ync & azing. \\
\hline
\end{tabular}

